\title{
The effects of corporate governance on stock liquidity: Evidence from Tehran Stock Exchange
}

\author{
Aboubakr Arazpour $^{\mathrm{a}^{*}}$ and Mohammad Esmaeil Fadaeinejad ${ }^{\mathrm{b}}$
}

${ }^{a}$ MSc of Finance, University of Economic Science, University of Economic Sciences, Tehran, Iran

${ }^{b}$ Assistant Professor, Department of Management and Accounting, Shahid Beheshti University, Tehran, Iran

\section{H R O N I C L E}

\section{Article history:}

Received December 2, 2013

Accepted 8 May 2014

Available online

May 152014

Keywords:

Corporate Governance

Liquidity

Ownership structure

Board independence

Tehran Securities Exchange

\begin{abstract}
A B S T R A C T
This study examines the relationship between corporate governance's mechanisms and liquidity of stocks on 66 selected firms listed on Tehran Stock Exchange over the period 2005-2009. Board composition and ownership structure are used as corporate governance's mechanisms and illiquidity measure proposed by Amihud (2002) [Amihud, Y. (2002). Illiquidity and stock returns: cross-section and time-series effects. Journal of financial markets, 5(1), 31-56.] is used to measure stock liquidity. The results show that an increase on the number of independent boards is associated with higher liquidity. In addition, the results show that there was a significant relationship between liquidity and ownership structure. In other words, the relationships between liquidity and individual investors and five biggest investors are positive and the relationships between liquidity and institutional ownership and the biggest investor ownership are negative. In addition, there is not a significant relationship between liquidity and duality of managers.
\end{abstract}

\section{Introduction}

One of the primary concerns on most stock exchanges is to increase the liquidity level and increase the number of shares traded and there are many studies associated with this issue (Datar et al., 1998; Subrahmanyam, 1991; Ajinkya et al., 2005; Haniffa \& Cooke, 2002, 2005; Chung et al., 2010). Acharya and Pedersen (2005), for instance, solved explicitly a simple equilibrium model with liquidity risk and reported that a persistent negative shock to a security's liquidity could yield in low contemporaneous returns and high predicted future returns. Amihud (2002) explained that over time, expected market illiquidity positively influences ex ante stock excess return, implying that expected stock excess return partly could represent an illiquidity premium. The difference between bid and ask normally describes liquidity and there are some investigations on the difference between bid and ask (Glosten \& Milgrom, 1985).

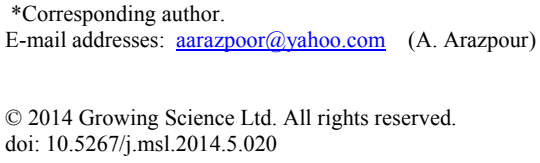


Amihud and Mendelson (1986) investigated the impact of the bid-ask spread on asset pricing and analyzed a model in which investors with various expected holding periods trade assets with various relative spreads. They reported that market-observed expected return was an increasing and concave function of the spread. Amihud et al. (1999) provided some similar investigation and results on Japanese stock exchange. Brennan and Subrahmanyam (1995) investigated the relationship between the number of analysts following a security and the estimated adverse selection expense of transacting in the security, controlling for the impacts of previously identified determinants of liquidity.

Brockman and Chung (2003) investigated the relationship between investor protection and firm liquidity and reported that firm liquidity was significantly influenced by investor protection. Chen and Jaggi (2001) did a survey to find out whether comprehensive financial disclosures, applied as a proxy for corporate board's responsiveness, were positively associated with the proportion of independent non-executive directors (INDs) on corporate boards, and whether family control of the firm maintained any effect on this association. They reported that the ratio of INDs to the total number of directors on corporate boards was positively associated with the comprehensiveness of financial disclosures, and this association seemed to be weaker for family controlled companies compared with non-family controlled firms.

Cueto (2009) performed another investigation on market liquidity and ownership structure with weak protection for minority shareholders. Dumitrescu (2010) investigated the relationship between corporate governance and market liquidity and state that corporate governance could significantly influence on market liquidity. Foo and Zain (2010) investigated the effects of board independence, board diligence on liquidity of stocks in Malaysia and reported that these two variables could influence liquidity of stocks. Jacoby and Zheng (2010) investigated the relationship between ownership dispersion and market liquidity.

Karamanou and Vafeas (2005) performed an investigation to find out how corporate boards and audit committees were associated with voluntary financial disclosure practices. They reported that in companies with more effective board and audit committee structures, managers were more likely to make or update an earnings forecast, and their forecast was less likely to be precise, it was more accurate, and it elicited a more favorable market response. Another issue, which could influence negatively on trading stocks, is associated with insider trading (Meulbroek, 1992). Rhee and Wang (2009) studied the effects of foreign institutional ownership and stock market liquidity in Indonesia and reported that foreign holdings had a negative effect on future liquidity.

\section{The proposed study}

This study examines the relationship between corporate governance's mechanisms and liquidity of stocks on selected firms listed on Tehran Stock Exchange over the period 2005-2009. The main hypothesis of this survey is as follows,

Main hypothesis: There is a positive and meaningful relationship between corporate governance's mechanisms and liquidity of stocks (Jensen \& Meckling, 1976; Lang et al., 2003).

To examine the main hypothesis of the survey, we consider the following six hypotheses,

1. There is a positive and meaningful relationship between the relative extent of nonexecutive to executive directors and liquidity of stocks (Merton, 1987; Mendelson et al., 2004).

2. There is a significant difference between the liquidity of the firms with complex management components and the liquidity of the firms with non-complex management component. 
3. There is a meaningful relationship between institutional ownership structure and liquidity of stocks (Watts \& Zimmerman, 1986).

4. There is a meaningful relationship between the ownership ratios of the five biggest shareholders and liquidity of stocks (Rubin, 2007).

5. There is a meaningful relationship between the ownership ratios of the biggest shareholders and liquidity of stocks (Vafeas, 1999)

6. There is a meaningful relationship between the number of shares owned by individual shareholders and liquidity of stocks (Welker, 1995).

In our survey, BOARDC represents the relative extent of nonexecutive to executive directors. To measure complex management components we consider a dummy variable, which is one if managing director is also chair of directors and zero, otherwise. In addition, BIGOL represents the shares of the biggest shareholder, FBIGOL states the shares of the five biggest shareholders, INSTOL represents the institutional ownership ratio, which shows the number of shares owned by banks or financial institutions. In this survey, Board composition and ownership structure are used as corporate governance's mechanisms and illiquidity measure proposed by Amihud (2002) is used to measure stock liquidity. In addition, liquidity is calculated as follows,

ILLIQ $_{\text {it }}=\frac{1}{D_{\text {it }}} \sum_{d-1}^{D_{\text {it }}} \frac{\left|R_{\text {idt }}\right|}{V_{\text {idt }}}$

where $I L L I Q_{i t}, R_{i d t}, V_{i d t}$ and $D_{i t}$ represent the illiquidity of share, daily return, daily volume of transactions and the number of trading shares of share $i$ at time $t$, respectively. There are three control variables including debts ratio, firm size and volume of trades. In our survey, $L E V$ represents debt ratio, which is calculated as a ratio of total liabilities on total assets, SIZE represents the size of the firm, which is calculated as taking a natural logarithm on daily market value and finally VOLUME represents the volume of transactions, which measures the amount of shares traded on daily basis. The proposed study considers the following regression analysis,

$$
\begin{aligned}
& \text { LIQUIDITY }_{i t}=\alpha+\left(\beta_{1} B O A R D C_{i t}\right)+\left(\beta_{2} B_{I G O L}\right)+\left(\beta_{3} F_{B I G O L}\right)+\left(\beta_{4} I N S T O L_{i t}\right)+ \\
& \left(\beta_{5} I N D V O L_{i t}\right)+\left(\beta_{6} D U A L I T Y_{t}\right)+\left(\beta_{7} L E V_{i t}\right)+\left(\beta_{8} S I Z E_{i t}\right)+\left(\beta_{9} V O L U M E_{i t}\right)+\varepsilon_{i t}
\end{aligned}
$$

The process selects firms from Tehran Stock Exchanges and all the necessary information must be available during the course of investigation. Table 1 shows some basic statistics associated with our investigation.

\section{Table 1}

The results of some basic statistics associated with the proposed study

\begin{tabular}{cccc}
\hline Variable & Mean & Median & Standard deviation \\
\hline BOARDC & 0.4904 & 0.6 & 0.3302 \\
DUALITY & 0.0684 & 0.0 & 0.2529 \\
BIGOL & 0.4689 & 0.4844 & 0.1802 \\
FBIGOL & 0.7073 & 0.7308 & 0.1526 \\
INSTOL & 0.4112 & 0.3673 & 0.2579 \\
INDVOL & 0.5891 & 0.6326 & 0.2581 \\
ILLIQ & 0.00093 & 0.00025 & 0.00189 \\
VOLUME & 345782433296 & 81174802871 & 646733607296 \\
SIZE & 27.4 & 27.21 & 1.5096 \\
LEV & 0.5835 & 0.5869 & 0.2121 \\
\hline
\end{tabular}

\section{The results}

The proposed study uses stepwise regression analysis and Fig. 1 demonstrates the residuals. 

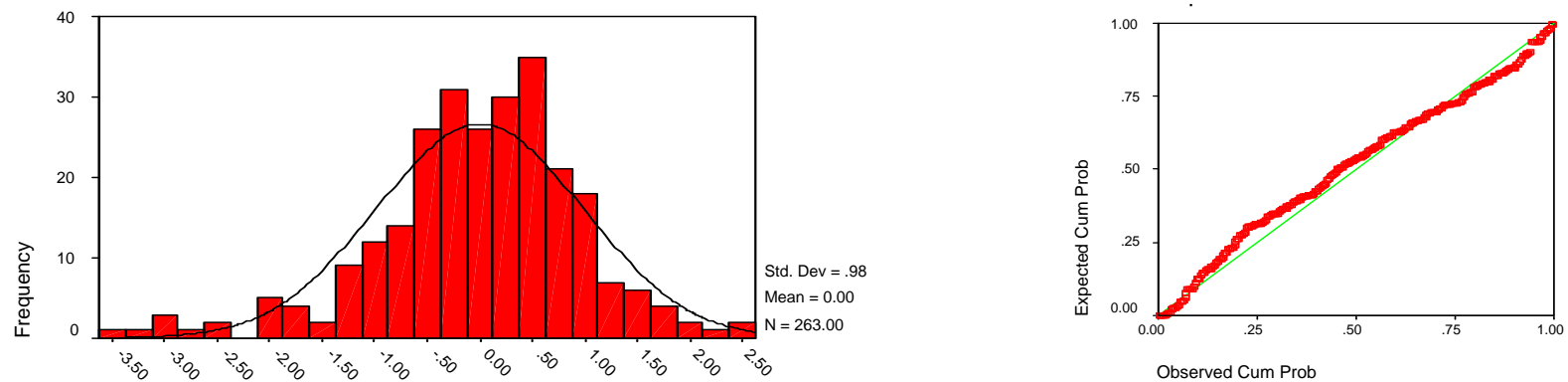

Fig. 1. The results of residuals

Based on the results of Fig. 1, we understand that all residuals are normally distributed. Table 2 demonstrates the results of regression analysis.

Table 2

The summary of regression analysis

\begin{tabular}{cccccc}
\hline Variable & $\beta$ & t statistics & Results & VIF & Sig. \\
\hline BOARDC & 2.629 & 35.64 & Confirmed & 5.527 & 0 \\
DUALITY & 1.143 & 0.912 & Not Confirmed & 1.498 & 0.363 \\
BIGOL & -0.081 & -3.071 & Not Confirmed & 3.83 & 0.002 \\
FBIGOL & 0.127 & 4.683 & Confirmed & 2.181 & 0 \\
INSTOL & -0.899 & -26.489 & Not Confirmed & 7.769 & 0 \\
INDVOL & 0.967 & 30.682 & Confirmed & 6.592 & 0 \\
VOLUME & $\left(10^{-14} \times 3.073\right)$ & -0.055 & Not Confirmed & 1.15 & 0.956 \\
SIZE & $10^{-12} \times 3.132$ & 1.833 & Not Confirmed & 1.267 & 0.068 \\
LEV & 3.199 & 1.953 & Not Confirmed & 2.12 & 0.052 \\
\hline
\end{tabular}

$\mathrm{F}$-value $=65.45 \mathrm{P}$-value $=0.000, \mathrm{R}^{2}=0.979$ Adjusted $\mathrm{R}^{2}=0.959$

As we can observe from the results of Table 2, all VIF numbers are between 0.1 and 10 and we can conclude that there is not any co-linearity. In addition, F-value is meaningful when the level of significance is one percent and Adjusted R-Square is equal to 0.959, which means the independent variables of regression describe approximately $96 \%$ of the changes on dependent variable. The results indicate that the effects of BOARDC, FBIGOL and INDVOL are significant.

\section{Conclusion}

This paper has investigated the relationship between corporate governance's mechanisms and liquidity of stocks on 66 selected firms listed on Tehran Stock Exchange over the period 2005-2009. Board composition and ownership structure are used as corporate governance's mechanisms and illiquidity measure proposed by Amihud (2002) has been applied to measure stock liquidity. The results have shown that an increase on the number of independent boards was associated with higher liquidity. In addition, there was a significant relationship between liquidity and ownership structure. In other words, the relationships between liquidity and individual investors and five biggest investors are positive and the relationships between liquidity and institutional ownership and the biggest investor ownership are negative. In addition, there is not a significant relationship between liquidity and duality of managers.

\section{Acknowledgement}

The authors would like to thank the anonymous referees for constructive comments on earlier version of this paper. 


\section{References}

Acharya, V. V., \& Pedersen, L. H. (2005). Asset pricing with liquidity risk. Journal of Financial Economics, 77(2), 375-410.

Ajinkya, B., Bhojraj, S., \& Sengupta, P. (2005). The association between outside directors, institutional investors and the properties of management earnings forecasts. Journal of accounting Research, 43(3), 343-376.

Amihud, Y. (2002). Illiquidity and stock returns: cross-section and time-series effects. Journal of financial markets, 5(1), 31-56.

Amihud, Y., \& Mendelson, H. (1986). Asset pricing and the bid-ask spread. Journal of financial Economics, 17(2), 223-249.

Amihud, Y., Mendelson, H., \& Uno, J. (1999). Number of shareholders and stock prices: Evidence from Japan. The Journal of finance, 54(3), 1169-1184.

Brennan, M. J., \& Subrahmanyam, A. (1995). Investment analysis and price formation in securities markets. Journal of Financial Economics, 38(3), 361-381.

Brockman, P., \& Chung, D. Y. (2003). Investor protection and firm liquidity. The Journal of Finance, 58(2), 921-938.

Chen, C. J., \& Jaggi, B. (2001). Association between independent non-executive directors, family control and financial disclosures in Hong Kong. Journal of Accounting and Public Policy, 19(4), 285-310.

Chung, K. H., Elder, J., \& Kim, J. C. (2010). Corporate governance and liquidity. Journal of Financial and Quantitative Analysis, 45(2), 265-291.

Cueto, D. C. (2009). Market liquidity and ownership structure with weak protection for minority shareholders: evidence from Brazil and Chile. Journal of Banking \& Finance, 31, 1771-1794.

Datar, V. T., Y Naik, N., \& Radcliffe, R. (1998). Liquidity and stock returns: An alternative test. Journal of Financial Markets, 1(2), 203-219.

Dumitrescu, A. (2010). Corporate governance and market liquidity. Financial Accounting and Reporting Research, 48 , 423-471.

Foo, Y. B., \& Zain, M. M. (2010). Board independence, board diligence and liquidity in Malaysia: A research note. Journal of Contemporary Accounting \& Economics, 6(2), 92-100.

Glosten, L. R., \& Milgrom, P. R. (1985). Bid, ask and transaction prices in a specialist market with heterogeneously informed traders. Journal of financial economics, 14(1), 71-100.

Haniffa, R. M., \& Cooke, T. E. (2002). Culture, corporate governance and disclosure in Malaysian corporations. Abacus, 38(3), 317-349.

Haniffa, R. M., \& Cooke, T. E. (2005). The impact of culture and governance on corporate social reporting. Journal of Accounting and Public Policy, 24(5), 391-430.

Healy, P. M., Hutton, A. P., \& Palepu, K. G. (1999). Stock performance and intermediation changes surrounding sustained increases in disclosure. Contemporary accounting research, 16(3), 485-520.

Holden, C. W., \& Subrahmanyam, A. (1992). Long-Lived Private Information and Imperfect Competition. The Journal of Finance, 47(1), 247-270.

Jacoby, G., \& Zheng, S. X. (2010). Ownership dispersion and market liquidity. International Review of Financial Analysis, 19(2), 81-88.

Jensen, M. C., \& Meckling, W. H. (1976). Theory of the firm: Managerial behavior, agency costs and ownership structure. Journal of financial economics, 3(4), 305-360.

Karamanou, I., \& Vafeas, N. (2005). The association between corporate boards, audit committees, and management earnings forecasts: An empirical analysis. Journal of Accounting research, 43(3), 453-486.

Lang, M. H., Lins, K. V., \& Miller, D. P. (2003). ADRs, analysts, and accuracy: Does cross listing in the United States improve a firm's information environment and increase market value?. Journal of Accounting Research, 41(2), 317-345.

Mendelson, H., \& Tunca, T. I. (2004). Strategic trading, liquidity, and information acquisition. Review of Financial Studies, 17(2), 295-337. 
Merton, R. C. (1987). A simple model of capital market equilibrium with incomplete information. The journal of finance, 42(3), 483-510.

Meulbroek, L. K. (1992). An empirical analysis of illegal insider trading. The Journal of Finance, 47(5), 1661-1699.

Rhee, S. G., \& Wang, J. (2009). Foreign institutional ownership and stock market liquidity: Evidence from Indonesia. Journal of Banking \& Finance, 33(7), 1312-1324.

Rubin, A. (2007). Ownership level, ownership concentration and liquidity. Journal of financial Markets, 10(3), 219-248.

Subrahmanyam, A. (1991). Risk aversion, market liquidity, and price efficiency. Review of Financial Studies, 4(3), 417-441.

Vafeas, N. (1999). Board meeting frequency and firm performance. Journal of financial economics, 53(1), 113-142.

Watts, R.L., \& Zimmerman, J.L. (1986). Positive Accounting Theory. Prentice Hall.

Welker, M. (1995). Disclosure policy, information asymmetry, and liquidity in equity markets. Contemporary accounting research, 11(2), 801-827. 